\title{
ZASTOSOWANIE METODY CCR-DEA DO OCENY EFEKTYWNOŚCI KSZTAŁCENIA W SZKOLNICTWIE WYŻSZYM W POLSCE
}

\section{WPROWADZENIE}

Kapitał ludzki jest kategorią coraz częściej uwzględnianą w teoriach wzrostu gospodarczego w związku z odbywającą się transformacją gospodarczą określana ,wchodzeniem w gospodarkę XXI w.” lub „,wchodzeniem w gospodarkę opartą na wiedzy". Zmieniające się środowisko, w którym działają przedsiębiorstwa, wymaga od potencjalnego pracownika wysokiej elastyczności i wykonywania coraz to nowych zadań, obsługi zaawansowanych technologicznie urządzeń oraz zdolności systematycznego, ciągłego przekwalifikowywania. Bezdyskusyjna jest rola, jaką w tych okolicznościach odgrywa edukacja, szczególnie na poziomie szkolnictwa wyższego. W latach 1995-2010 można zauważyć sukcesywny wzrost odsetka osób z wykształceniem wyższym, począwszy od poziomu 7,7\% osiągniętego w 1995 r., a skończywszy na poziomie 19,6\% w 2010 r. Powstaje pytanie, czy jest to przejaw wzrostu poziomu kapitału ludzkiego, czy raczej niepokojący symptom ,masowej produkcji dyplomów”.

Zadaniem szkolnictwa wyższego nie jest bowiem jedynie umożliwienie nabycia kwalifikacji wszystkim zainteresowanym, ale szkoły wyższe powinny również dokonywać właściwej alokacji studentów na kierunkach w zależności od zapotrzebowania rynku pracy na daną kadrę pracowniczą, aby zdolności i umiejętności absolwentów szkół wyższych nabyte w trakcie edukacji były tymi pożądanymi i poszukiwanymi przez potencjalnych pracodawców ${ }^{1}$. Niespełnienie tego postulatu grozi wysokim bezrobociem w grupie osób posiadających wykształcenie wyższe. R. Przybyszewski zaproponował kilka sposobów na zwiększanie efektywności polskiego systemu kształcenia ${ }^{2}$. Jako pierwszy wymienia konieczność powiązania rynku pracy z systemem edukacji przez

\footnotetext{
${ }^{1}$ Problem ten został naświetlony w samej Strategii Rozwoju Szkolnictwa Wyższego do roku 2020: „1. Niekorzystnie zmieniła się też struktura studiujących w podziale na główne grupy kierunków studiów mamy zbyt wielu absolwentów i studentów na kierunkach należących do grup »nauki społeczne, handel i prawo« oraz »kształcenie«, natomiast już wkrótce może brakować absolwentów kierunków z grup »zdrowie i opieka społeczna«, »nauka« oraz »technika, przemysł i budownictwo«. 2. Ilościowy wzrost sektora szkolnictwa wyższego, wychodzący naprzeciw społecznemu zapotrzebowaniu, wywołał jednak istotne problemy. W wielu obszarach towarzyszył mu spadek jakości kształcenia, a dydaktyka zaczęła w coraz większym stopniu wypierać działalność naukowo-badawczą".

${ }^{2}$ R. Przybyszewski, Kapitat ludzki w procesie ksztattowania gospodarki opartej na wiedzy, Difin, Warszawa 2007, s. 194.
} 
uwzględnienie w systemie kształcenia prognoz dotyczących zmian kierunków działania sektorów gospodarczych oraz prognoz zapotrzebowania na określonych specjalistów. Uważa on również, że jakość pracowników, która uzależnia od efektywności systemu edukacyjnego, wpływa na rozwój gospodarczy. Z tym poglądem zgadza się również Z. Wojciechowski, który postrzega jakość kapitału ludzkiego jako źródło uwarunkowań i relacji ekonomicznych w XXI w. ${ }^{3}$ G. S. Becker z kolei pisał, że kapitał ludzki pracowników jest proporcjonalny do kapitału ludzkiego nauczycieli, a współczynnik proporcjonalności zależy od wartości wskaźnika liczby nauczycieli przypadających na jednego studenta (teacher-student ratio) ${ }^{4}$. Współczynnik ten ma bardzo istotne znaczenie, ponieważ określa, ile czasu nauczyciel jest w stanie poświęcić swojemu studentowi, co z kolei może wpływać na jakość kształcenia.

Zatem w badaniu efektywności szkolnictwa wyższego w zakresie kształcenia powinno uwzględniać się nie tylko to, co się dzieje w trakcie edukacji wyższej jeszcze przed otrzymaniem dyplomu, lecz także poza ramami uczelni: ocenić, jak absolwenci radzą sobie z poszukiwaniem pracy i czy ich kwalifikacje zdobyte $\mathrm{w}$ trakcie edukacji sa pożądane przez potencjalnych pracodawców. Można powiedzieć, że te szkoły wyższe, które dostarczają na rynek pracy dużej liczby osób z wykształceniem wyższym przy stosunkowo niskim zatrudnieniu nauczycieli akademickich, stawiają na tak zwaną masowość kształcenia. Aby ocenić stopień „odpowiedniości” kształcenia, a więc stopień właściwej alokacji studentów na kierunkach strategicznych oraz jakość wiedzy i zdobytych umiejętności, należałoby sprawdzić, jak absolwenci tych szkół radzą sobie na rynku pracy.

Głównym celem niniejszego artykułu jest ocena polskich województw pod względem efektywności kształcenia w szkolnictwie wyższym w zakresie „,masowości” i ,odpowiedniości” oraz zbadanie, czy stawianie na „masowość” kształcenia przyczynia się do poprawy sytuacji na rynku pracy. Pierwsze podejście badające stopień „,masowości” kształcenia określa, jak efektywnie województwa podnosiły kwalifikacje mieszkańców regionu. Drugie podejście z kolei pozwala ocenić efektywność odnajdowania się absolwentów szkół wyższych na rynku pracy, a więc ocenie poddana jest jakość tego wykształcenia i stopień właściwej alokacji studentów na strategicznych z punktu widzenia przyszłego rozwoju gospodarczego kierunkach studiów, co nazwano właśnie „odpowiedniością” kształcenia.

Badania zostały przeprowadzone na podstawie danych statystycznych pochodzących z bazy Głównego Urzędu Statystycznego i obejmowały lata 2006-2007. Analizę przeprowadzono za pomoca metody CCR-DEA (Data Envelopment Analysis). W kolejnych częściach artykułu przybliżono metodykę badań naukowych, sformułowano definicję badanej efektywności, przytoczono podstawy teoretyczne zastosowanej metody DEA, a następnie opisano wyniki badań empirycznych oraz sformułowano płynące z nich wnioski.

${ }^{3}$ Z. Wojciechowski, Jakość kapitału ludzkiego w procesie tworzenia konkurencyjności przedsiębiorstwa, w: K. Piotrkowski (red.), Zarzadzanie potencjatem ludzkim w organizacji XXI wieku, Wojskowa Akademia Techniczna, Warszawa 2006, s. 45-69.

${ }^{4}$ G. S. Becker, Human Capital. A Theoretical and Empirical Analysis with Special Reference to Education, The National Bureau of Economic Research, USA, 1993, s. 315. 


\section{METODYKA BADAŃ NAUKOWYCH}

Przeprowadzona w niniejszym artykule analiza składała się z dwóch etapów. Pierwszy etap polegał na zbadaniu, jak efektywnie województwa w latach 2006-2007 kształciły studentów w sensie ilościowym; w drugim - jak efektywnie województwa wypadaja pod względem jakości wykształcenia czy inaczej: zdolności do takiej alokacji studentów na różnych kierunkach studiów, aby zaspokoić wymagania stawiane przez rynek pracy. Badana $\mathrm{w}$ niniejszych analizach efektywność to tak zwana efektywność techniczna (technologiczna) obiektów. W celu jej oszacowania wykorzystano metodę CCR-DEA. Po oszacowaniu współczynników efektywności pogrupowano polskie województwa najpierw ze względu na wartości współczynników efektywności uzyskane na pierwszym etapie analizy i porównano średnie wartości współczynników efektywności oszacowane na etapie drugim w poszczególnych klasach. Zabieg ten miał na celu wskazanie tendencji zaniedbywania jakości wykształcenia przez szkoły wyższe działające w województwach nastawionych na „masowość” kształcenia.

Dowolny proces gospodarczy można rozważać od strony poniesionych nakładów lub uzyskanych rezultatów. Uwzględnienie obu tych aspektów jest elementem kluczowym $\mathrm{w}$ badaniu efektywności. W niniejszych badaniach przeanalizowano dwa procesy: proces podnoszenia kwalifikacji (pierwszy etap-„masowość kształcenia”) oraz proces właściwej alokacji studentów (drugi etap - ,odpowiedniość” kształcenia).

Wzięty pod uwagę na pierwszym etapie analizy układ nakładów i rezultatów został zaprezentowany poniżej:

$\mathrm{X}_{1}$ - dostęp do nauczycieli akademickich (liczba nauczycieli akademickich na 1000 studentów),

$\mathrm{X}_{2}$ - dostęp do edukacji (liczba szkół wyższych na mieszkańca w wieku $19+)$,

$\mathrm{Y}_{1}$ - poziom wykształcenia (odsetek osób $\mathrm{z}$ wykształceniem wyższym w populacji w wieku $25+$ ).

Współczynnik efektywności uzyskany na tym etapie badania nazwano współczynnikiem efektywności w zakresie „,masowości” kształcenia.

Układ nakładów i rezultatów na drugim etapie analizy wyglądał następująco:

$\mathrm{X}_{1}$ - poziom wykształcenia (odsetek osób $\mathrm{z}$ wykształceniem wyższym w populacji w wieku $25+$ ),

$\mathrm{Y}_{1}$ - jakość kwalifikacji 1 (odsetek zatrudnionych $\mathrm{z}$ wykształceniem wyższym wśród wszystkich aktywnych zawodowo pracujących),

$\mathrm{Y}_{2}$ - jakość kwalifikacji 2 (odsetek pracujących po raz pierwszy absolwentów wśród wszystkich absolwentów szkół wyższych).

Współczynnik efektywności uzyskany na tym etapie badania nazwano współczynnikiem efektywności w zakresie „odpowiedniości” kształcenia.

Nim jeszcze omówione zostaną wyniki badań empirycznych, poniżej wyjaśniono, jaki typ efektywności badano $\mathrm{w}$ przeprowadzonych analizach empirycznych, oraz opisano podstawy teoretyczne zastosowanego modelu CCR-DEA. 


\section{Efektywność techniczna Farrella}

Istnieją różne typy efektywności, jednak najczęściej przytaczana i najważniejsza z punktu widzenia zastosowanej metody badania efektywności jest efektywność techniczna Farrella. Jest to relacja uzyskanego rezultatu w stosunku do maksymalnego rezultatu możliwego do uzyskania przy danym poziomie nakładów lub relacja minimalnych nakładów możliwych do wykorzystania w stosunku do nakładów faktycznie poniesionych w celu uzyskania określonego poziomu rezultatu. Pierwsza definicja określa pojęcie efektywności technicznej ukierunkowanej na rezultaty, natomiast druga odnosi się do efektywności technicznej ukierunkowanej na nakłady. W przeprowadzonych analizach empirycznych zbadano drugi typ efektywności technicznej.

W celu zilustrowania efektywności technicznej Farrella rozważmy proces, w którym do uzyskania rezultatu w ilości y zużywa się dwóch nakładów w wielkości $x_{1}$ i $x_{2}$. O każdym obiekcie wiemy, ile jednostek nakładu każdego rodzaju wykorzystano do wyprodukowania jednej jednostki rezultatu. Na wykresie zaprezentowano zatem rozrzut wartości $\frac{x_{2}}{y}$ względem $\frac{x_{1}}{y}$.

Wykres 1

Graficzna prezentacji efektywności w sensie Farrella

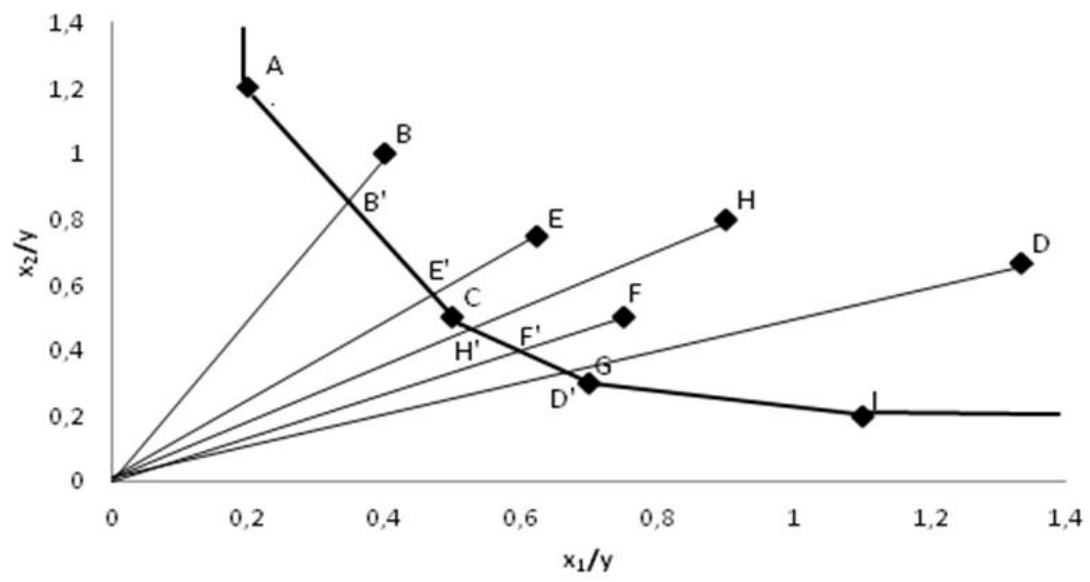

Źródło: opracowanie własne.

Linia pogrubiona na wykresie to granica efektywna, czyli linia, na której znajdują się obiekty w pełni efektywne $(A, C, G, I$ z przykładu). Pozostałe obiekty są nieefektywne. Linie na wykresie biegnące od punktów odpowiadających obiektom niefektywnym do początku układu współrzędnych i przecinające granice efektywne to tak zwane promienie technologiczne. Punkt przecięcia promienia technologicznego i granicy efektywnej wyznacza poziom proporcjonalnej redukcji nakładów wykorzystywanych przez obiekt nie- 
efektywny, przy którym jeszcze możliwe jest uzyskanie jednostki rezultatu. Zatem współczynnik efektywności technicznej Farrella można obliczyć jako:

$$
\underset{n=1,2, \ldots N}{\forall} \theta_{n}=\frac{d\left(O_{n}^{\prime} ; O\right)}{d\left(O_{n} ; O\right)},
$$

gdzie:

$\theta_{n}$ - współczynnik efektywności technicznej Farrella, $d\left(O_{n}^{\prime} ; O\right)$ - odległość punktu przecięcia promienia technologicznego obiektu $n$-tego z granica efektywną od początku układu współrzędnych, $d\left(O_{n} ; O\right)$ - odległość punktu odpowiadającego nakładom poniesionym przez obiekt $n$-ty od początku układu współrzędnych.

Zatem ukierunkowana na nakłady efektywność techniczna Farrella obiektu $n-\vartheta_{n}$ to możliwie maksymalna proporcjonalna redukcja poniesionych przez obiekt $n$ nakładów do poziomu $\vartheta_{n}$-krotności faktycznie poniesionych, przy której możliwe jest jeszcze wypracowanie zaobserwowanego w obiekcie $n$ poziomu rezultatów.

\section{Model CCR-DEA}

Efektywność techniczna Farrella jest efektywnością powszechnie badaną za pomoca metod z rodziny modeli efektywności radialnej DEA. Wybór metod $\mathrm{z}$ rodziny DEA podyktowany jest przede wszystkim tym, że pozwalają one na analizowanie efektywności obiektów przy jednoczesnym uwzględnieniu wielu nakładów i wielu rezultatów ${ }^{5}$. Najstarszym modelem z rodziny DEA był zaproponowany przez Charnesa, Coopera i Rhodesa w 1978 r. model CCR. Model ten doczekał się bardzo dużej liczby różnych modyfikacji, z których B. Guzik jako najważniejsze z punktu widzenia interpretacji ekonomicznej wymienia dwa: model nadefektywności (super-efficiency) oraz model efektywności nieradialnej (non-radial efficiency) ${ }^{6}$. W niniejszym artykule do pomiaru efektywności szkolnictwa wyższego w zakresie kształcenia zastosowano pierwotny model $\mathrm{CCR}^{7}$.

Warto w tym miejscu jeszcze przed przystapieniem do omówienia modelu CCR-DEA poczynić kilka założeń i przytoczyć parę definicji. Niech zatem $N$ oznacza liczbę analizowanych obiektów, $T$ - liczbę nakładów, natomiast $R$ - liczbę rezultatów.

5 ,Nakłady to wielkości umożliwiające uzyskiwanie takich czy innych rezultatów działalności. [...] Efektywność technologiczna to skuteczność przekształcania nakładów w rezultaty". B. Guzik, Podstawowe modele DEA w badaniu efektywności gospodarczej i społecznej, Wydawnictwo Uniwersytetu Ekonomicznego w Poznaniu, Poznań 2009, s. 20-21.

${ }^{6}$ Ibidem, s. 27.

${ }^{7}$ Więcej nt. tego modelu: ibidem, s. 55-105. A. Domagała, Przestrzenno-czasowa analiza efektywności jednostek decyzyjnych metoda Data Envelopment Analysis na przykładzie banków polskich, „Badania Operacyjne i Decyzje” 2007, nr 3-4, s. 35-56; eadem, Metoda Data Envelopment Analysis jako narzedzie badania względnej efektywności technicznej, „Badania Operacyjne i Decyzje” 2007, nr 3-4, s. 21-34; B. Guzik, Podstawowe możliwości analityczne modelu CCR-DEA, „Badania Operacyjne i Decyzje” 2009, nr 1, s. 55-75. 
- Przez pojęcie „technologia empiryczna $n$-tego obiektu $\left(T_{n}\right)$ ” rozumie się wektor zaobserwowanych wartości nakładów i rezultatów postaci:

$$
T_{n}=\left[\begin{array}{c}
x_{1} \\
\cdots \\
x_{T} \\
y_{1} \\
\cdots \\
y_{R}
\end{array}\right],
$$

gdzie:

$x_{t}$ - wartość $t$-tego nakładu,

$y_{r}$ - wartość $r$-tego rezultatu.

- Przez pojęcie ,technologia wspólna zbioru obiektów $\left(T^{w}\right)$ ” rozumie się kombinację liniową technologii empirycznych poszczególnych obiektów należących do tego zbioru:

$$
T^{w}=\lambda_{1} T_{1}+\lambda_{2} T_{2}+\ldots+\lambda_{N} T_{N},
$$

gdzie:

$T_{n}$ - technologia empiryczna $n$-tego obiektu, $\lambda_{n}(n=1,2, \ldots, N)$ - nieujemne liczby rzeczywiste (wagi intensywności).

- Przez pojęcie ,zorientowana na $n$-ty obiekt technologia wspólna zbioru obiektów" $\left(T_{n}^{w}\right)$ rozumie się taką liniową kombinację technologii empirycznych poszczególnych obiektów należących do tego zbioru, która pozwala uzyskać rezultaty obiektu $n$-tego nakładami nie większymi od tych, ponoszonych w technologii empirycznej obiektu $n$-tego.

Każda technologia wspólna zbioru obiektów jest „technologią dopuszczalna”. Zbiór wszystkich technologii dopuszczalnych ustalonych przy wszystkich możliwych kombinacjach współczynników $\lambda_{n}(n=1,2, \ldots, N)$ nazywany jest „przestrzenią produkcyjną".

Ustalenie efektywności w modelu CCR sprowadza się do ustalenia optymalnych współczynników $\lambda_{n}(n=1,2, \ldots, N)$ w zbiorze zorientowanych na dany obiekt technologiach wspólnych zbioru obiektów. Ustalanie optymalnych wag intensywności może równoważnie przebiegać w dwóch kierunkach:

a) minimalizowane sa nakłady niezbędne do uzyskania rezultatów nie mniejszych od osiagniętych przez badany obiekt (zadanie ukierunkowane na nakłady),

b) maksymalizowane są rezultaty możliwe do osiagnięcia przy nakładach nie większych od poniesionych przez badany obiekt (zadanie ukierunkowane na rezultaty).

W niniejszym artykule zastosowano model CCR ukierunkowany na nakłady, który można zapisać następująco:

Funkcja celu:

$\theta_{n} \rightarrow \min \left[\theta_{n}-\right.$ współczynnik efektywności obiektu $n$-tego $]$ 
Warunki ograniczające:

$$
\begin{gathered}
\lambda_{n, 1}\left[\begin{array}{c}
x_{1} \\
x_{2} \\
\ldots \\
x_{T}
\end{array}\right]+\lambda_{n, 2}\left[\begin{array}{c}
x_{1} \\
x_{2} \\
\ldots \\
x_{T}
\end{array}\right]+\ldots+\lambda_{n, N}\left[\begin{array}{c}
x_{1} \\
x_{2} \\
\ldots \\
x_{T}
\end{array}\right] \leqslant \theta_{n}\left[\begin{array}{l}
x_{1} \\
x_{2} \\
\ldots \\
x_{T}
\end{array}\right], \\
\lambda_{n, 1}\left[\begin{array}{c}
y_{1} \\
y_{2} \\
\ldots \\
y_{R}
\end{array}\right]+\lambda_{n, 2}\left[\begin{array}{c}
y_{1} \\
y_{2} \\
\ldots \\
y_{R}
\end{array}\right]+\ldots+\lambda_{n, N}\left[\begin{array}{c}
y_{1} \\
y_{2} \\
\ldots \\
y_{R}
\end{array}\right] \geqslant\left[\begin{array}{c}
y_{1} \\
y_{2} \\
\ldots \\
y_{R}
\end{array}\right], \\
\theta_{n}, \lambda_{n, 1}, \lambda_{n, 2}, \ldots, \lambda_{n, N} \geqslant 0 .
\end{gathered}
$$

Współczynnik efektywności $\theta_{n}=1$, świadczy o tym, że obiekt $n$-ty jest w pełni efektywny, co oznacza, że technologią optymalną w zbiorze zorientowanych na ten obiekt technologii wspólnych jest technologia empiryczna tego obiektu ${ }^{8}$.

Dla ustalonego wskaźnika $\theta_{n}$ oraz układu wag intensywności $\left[\lambda_{n, 1}, \lambda_{n, 2}, \ldots, \lambda_{n, N}\right]$ technologia $T_{n}^{\text {efektywna }}=\theta_{n}\left[\begin{array}{c}x_{1} \\ \cdots \\ x_{T} \\ y_{1} \\ \cdots \\ y_{R}\end{array}\right]$ określana jest mianem technologii efektywnej, natomiast technologia $T_{n}^{\text {optymalna } \ln a}=\lambda_{n, 1}\left[\begin{array}{c}x_{1} \\ x_{2} \\ \cdots \\ x_{T} \\ y_{1} \\ \cdots \\ y_{R}\end{array}\right]{ }^{1}+\lambda_{n, 2}\left[\begin{array}{c}x_{1} \\ x_{2} \\ \cdots \\ x_{T} \\ y_{1} \\ \ldots \\ y_{R}\end{array}\right]+\ldots+\lambda_{n, N}\left[\begin{array}{c}x_{1} \\ x_{2} \\ \cdots \\ x_{T} \\ y_{1} \\ \cdots \\ y_{R}\end{array}\right]$ to technologia optymalna.

${ }^{8}$ Nie oznacza to jednak, że obiekt $o$-ty ma największy poziom rezultatów. Należy pamiętać, że metoda DEA ustala efektywność w danym zbiorze obiektów. Modyfikacja zbioru obiektów (usunięcie lub wprowadzenie jakiegoś obiektu) może istotnie zmienić wyniki analiz. Więcej na ten temat w: B. Guzik, Podstawowe modele DEA..., passim. 


\section{WYNIKI BADAŃ EMPIRYCZNYCH}

W niniejszej części artykułu zaprezentowane zostaną wyniki przeprowadzonych analiz. Jak wspomniano, niniejsze badania empiryczne polegały na oszacowaniu współczynników efektywności szkolnictwa wyższego polskich województw. Obiektami poddanymi analizie porównawczej były polskie województwa, a dane pochodziły z bazy Głównego Urzędu Statystycznego z lat 2006 i 2007. W pierwszej części zostaną omówione wyniki pierwszego etapu analizy, a więc współczynniki efektywności w zakresie „masowości” kształcenia, w kolejnym wyniki drugiego etapu polegającego na badaniu efektywności w zakresie „odpowiedniości” kształcenia. Na koniec podjęto próbę porównania

\section{Tabela 1}

Wartości współczynników efektywności w zakresie „masowości” kształcenia poszczególnych województw w latach 2006 i 2007

\begin{tabular}{|l|l|l|}
\hline \multirow{2}{*}{\multicolumn{1}{|c|}{ Nazwa województwa }} & \multicolumn{2}{c|}{ Współczynnik efektywności } \\
\cline { 2 - 3 } & $\mathbf{2 0 0 6}$ & $\mathbf{2 0 0 7}$ \\
\hline DOLNOSLĄSKIE & 0,818 & 0,886 \\
\hline KUJAWSKO-POMORSKIE & 0,608 & 0,648 \\
\hline LUBELSKIE & 0,834 & 0,941 \\
\hline LUBUSKIE & 0,955 & 0,986 \\
\hline ŁODZKIE & 0,889 & 0,950 \\
\hline MAŁOPOLSKIE & 0,839 & 0,877 \\
\hline MAZOWIECKIE & 1 & 1 \\
\hline OPOLSKIE & 0,967 & 1 \\
\hline PODKARPACKIE & 0,880 & 0,958 \\
\hline PODLASKIE & 0,576 & 0,631 \\
\hline POMORSKIE & 0,642 & 0,692 \\
\hline ŚLĄSKIE & 0,877 & 0,883 \\
\hline ŚWIE TOKRZYSKIE & 1 & 1 \\
\hline WARMIŃSKO-MAZURSKIE & 1 & 0,992 \\
\hline WIELKOPOLSKIE & 0,763 & 0,743 \\
\hline ZACHODNIOPOMORSKIE & 0,718 & 0,754 \\
\hline Srednia: & 0,835 & 0,871 \\
\hline Odchylenie standardowe: & 0,140 & 0,133 \\
\hline Współczynnik zmienności: & $16,8 \%$ & $15,3 \%$ \\
\hline
\end{tabular}

Źródło: obliczenia własne. 
tych dwóch analiz w celu zbadania zależności pomiędzy „masowością” kształcenia a sytuacja na rynku pracy analizowanych województw oraz sformułowano pewne wnioski i sugestie dotyczące kształcenia w województwie wielkopolskim.

\section{Efektywność w zakresie „masowości” kształcenia}

W tabeli 1 zaprezentowano wartości wskaźników efektywności technicznej w zakresie „masowości” kształcenia dla lat 2006 i 2007 w poszczególnych województwach. W 2006 r. w pełni efektywne okazały się województwa mazowieckie, świętokrzyskie i warmińsko-mazurskie. Oznacza to, że ten sam odsetek ludności z wykształceniem wyższym nie mógłby zostać osiągnięty przy mniejszej dostępności kadry akademickiej oraz gorszym dostępie do edukacji, a więc województwa te $\mathrm{w}$ pełni wykorzystały swoje nakłady. W $2007 \mathrm{r}$. województwo warmińsko-mazurskie odznaczało się niższa efektywnościa $(0,992)$, a do grupy województw w pełni efektywnych (województwa mazowieckie i świętokrzyskie) w kolejnym analizowanym okresie dołączyło województwo opolskie. Najmniej efektywnym województwem było województwo podlaskie, które zarówno w 2006, jak i w 2007 r. osiągnęło najniższe wartości współczynnika efektywności równe, odpowiednio, 0,576 i 0,631.

\section{Efektywność w zakresie „odpowiedniości” kształcenia}

W tabeli 2 zaprezentowano wartości wskaźników efektywności technicznej w zakresie ,odpowiedniości” kształcenia dla lat 2006 i 2007 w poszczególnych województwach. W 2006 r. w pełni efektywne okazały się województwa opolskie, pomorskie i zachodniopomorskie. Oznacza to, że województwa te takie same rezultaty mierzone odsetkiem zatrudnionych posiadajacych wykształcenie wyższe oraz odsetkiem pracujących po raz pierwszy absolwentów szkół wyższych nie mogłyby zostać osiągnięte przy mniejszym odsetku osób $\mathrm{z}$ wykształceniem wyższym, a więc województwa te $\mathrm{w}$ pełni wykorzystały kwalifikacje mieszkańców. W 2007 r. województwo pomorskie nie było już w pełni efektywne (współczynnik efektywności wyniósł 0,989), a grupę województw w pełni efektywnych utworzyły dwa wspomniane wcześniej województwa: pomorskie i zachodniopomorskie. Najmniej efektywnym województwem było województwo lubelskie, które zarówno w 2006, jak i w 2007 r. osiagnęło najniższe wartości współczynnika efektywności równe, odpowiednio, 0,742 i 0,746 . 


\section{Tabela 2}

Wartości współczynników efektywności w zakresie „odpowiedniości” kształcenia poszczególnych województw w latach 2006 i 2007

\begin{tabular}{|l|l|l|}
\hline \multirow{2}{*}{ Nazwa województwa } & \multicolumn{2}{c|}{ Współczynnik efektywności } \\
\cline { 2 - 3 } & $\mathbf{2 0 0 6}$ & $\mathbf{2 0 0 7}$ \\
\hline DOLNOŚLA̧SKIE & 0,890 & 0,958 \\
\hline KUJAWSKO-POMORSKIE & 0,975 & 0,972 \\
\hline LUBELSKIE & 0,742 & 0,746 \\
\hline LUBUSKIE & 0,844 & 0,818 \\
\hline ŁÓDZKIE & 0,806 & 0,749 \\
\hline MAŁOPOLSKIE & 0,815 & 0,853 \\
\hline MAZOWIECKIE & 0,844 & 0,815 \\
\hline OPOLSKIE & 1 & 1 \\
\hline PODKARPACKIE & 0,855 & 0,854 \\
\hline PODLASKIE & 0,981 & 0,925 \\
\hline POMORSKIE & 1 & 0,989 \\
\hline SLAtSKIE & 0,930 & 0,938 \\
\hline ŚWIETOKRZYSKIE & 0,750 & 0,748 \\
\hline WARMIŃSKO-MAZURSKIE & 0,912 & 0,878 \\
\hline WIELKOPOLSKIE & 0,899 & 0,871 \\
\hline ZACHODNIOPOMORSKIE & 1 & 1 \\
\hline Średnia: & 0,890 & 0,882 \\
\hline Odchylenie standardowe: & 0,087 & 0,091 \\
\hline Współczynnik zmienności: & $9,8 \%$ & $10,3 \%$ \\
\hline
\end{tabular}

Źródło: obliczenia własne.

\section{Efektywność w zakresie „masowości” a efektywność w zakresie „odpowiedniości” kształcenia}

Dla 2006 i 2007 r. obliczono współczynniki efektywności szkół wyższych w zakresie „masowości” oraz ,odpowiedniości” kształcenia, przy czym pierwszy typ dotyczył efektywności podnoszenia kwalifikacji w sensie ilościowym, natomiast drugi badał, jak efektywnie te kwalifikacje pomagaja absolwentom odnaleźć się na rynku pracy. Współczynnik korelacji obliczony dla obu „typów” współczynników efektywności w 2006 r. wynosi: - 0,54, natomiast dla 2007 r.: $-0,56$. Istnieje zatem statystycznie istotna i ujemna współzależność pomiędzy 
wartościami tych dwóch współczynników efektywności, co sugeruje, że województwa charakteryzujące się wysokim (niskim) współczynnikiem efektywności w zakresie „masowości” kształcenia posiadają zwykle niski (wysoki) co do wartości współczynnik efektywności w zakresie ,odpowiedniości” kształcenia. W celu szczegółowej analizy przeprowadzono podział województw na skupienia $^{9}$. Za pierwsze kryterium podziału przyjęto współczynnik efektywności w zakresie „masowości” kształcenia. Policzono następnie wartości średnie, odchylenia standardowe, zmienności współczynników efektywności dla każdego skupienia i uzyskano następujące wyniki:

* $2006 \mathrm{r}$.

I grupa - lubelskie, świętokrzyskie,

II grupa - łódzkie, małopolskie, mazowieckie, lubuskie, podkarpackie, dolnośląskie,

III grupa - wielkopolskie, warmińsko-mazurskie, śląskie, kujawsko-pomorskie, IV grupa - podlaskie, opolskie, pomorskie, zachodniopomorskie.

\section{Tabela 3}

Wartości średnich, odchyleń standardowych i współczynników zmienności efektywności w zakresie ,masowości” kształcenia w 2006 r.

\begin{tabular}{|c|c|c|c|c|c|c|}
\hline \multirow[b]{2}{*}{$\begin{array}{c}\text { Numer } \\
\text { skupienia }\end{array}$} & \multicolumn{2}{|c|}{ Średnie } & \multicolumn{2}{|c|}{$\begin{array}{l}\text { Odchylenia } \\
\text { standardowe }\end{array}$} & \multicolumn{2}{|c|}{$\begin{array}{l}\text { Współczynniki } \\
\text { zmienności }\end{array}$} \\
\hline & $\begin{array}{l}\text { efektywność } \\
\text { w zakresie } \\
\text { „masowości” }\end{array}$ & $\begin{array}{c}\text { efektywność } \\
\text { w zakresie } \\
\text { „odpowied- } \\
\text { niości” }\end{array}$ & $\begin{array}{l}\text { efektywność } \\
\text { w zakresie } \\
\text { „masowości” }\end{array}$ & $\begin{array}{l}\text { efektywność } \\
\text { w zakresie } \\
\text { „odpowied- } \\
\text { niości” }\end{array}$ & $\begin{array}{l}\text { efektywność } \\
\text { w zakresie } \\
\text { „masowości” }\end{array}$ & $\begin{array}{c}\text { efektywność } \\
\text { w zakresie } \\
\text { „odpowied- } \\
\text { niości” }\end{array}$ \\
\hline I & 0,6085 & 0,9853 & 0,0329 & 0,0130 & $5,41 \%$ & $1,32 \%$ \\
\hline II & 0,7829 & 0,8827 & 0,0530 & 0,1064 & $6,78 \%$ & $12,05 \%$ \\
\hline III & 0,9012 & 0,8752 & 0,0496 & 0,0751 & $5,50 \%$ & $8,58 \%$ \\
\hline IV & 1,0000 & 0,8356 & 0,0000 & 0,0816 & $0,00 \%$ & $9,76 \%$ \\
\hline
\end{tabular}

Źródło: obliczenia własne.

Współczynniki efektywności w zakresie „masowości” kształcenia są w tym podziale w obrębie poszczególnych skupień zdecydowanie mniej zróżnicowane niż współczynniki efektywności w zakresie „odpowiedniości” kształcenia (tabela 3). Województwa $\mathrm{z}$ grupy I charakteryzuja się najniższą średnią

\footnotetext{
${ }^{9}$ Klasyfikacji dokonano, najpierw opierając się na współczynniku efektywności w zakresie „masowości” kształcenia, a następnie na współczynniku efektywności w zakresie „odpowiedniości” kształcenia i obliczając za każdym razem statystyki opisowe: średnią $\mu$ i odchylenie standardowe $\sigma$. Następnie dokonano podziału województw na cztery grupy w zależności od wartości współczynnika efektywności. Wartości graniczne, które posłużyły do grupowania to: $\mu-\sigma, \mu, \mu+\sigma$. Numery grup zostały tak przyporządkowane, aby do grupy o niższym numerze należały wszystkie województwa charakteryzujące się najniższymi wartościami współczynnika efektywności, według którego dany podział był ustalany.
} 


\section{Wykres 2}

Średnie poziomy współczynników efektywności w skupieniach wyznaczonych na podstawie współczynników efektywności w zakresie „masowości” kształcenia w 2006 r.

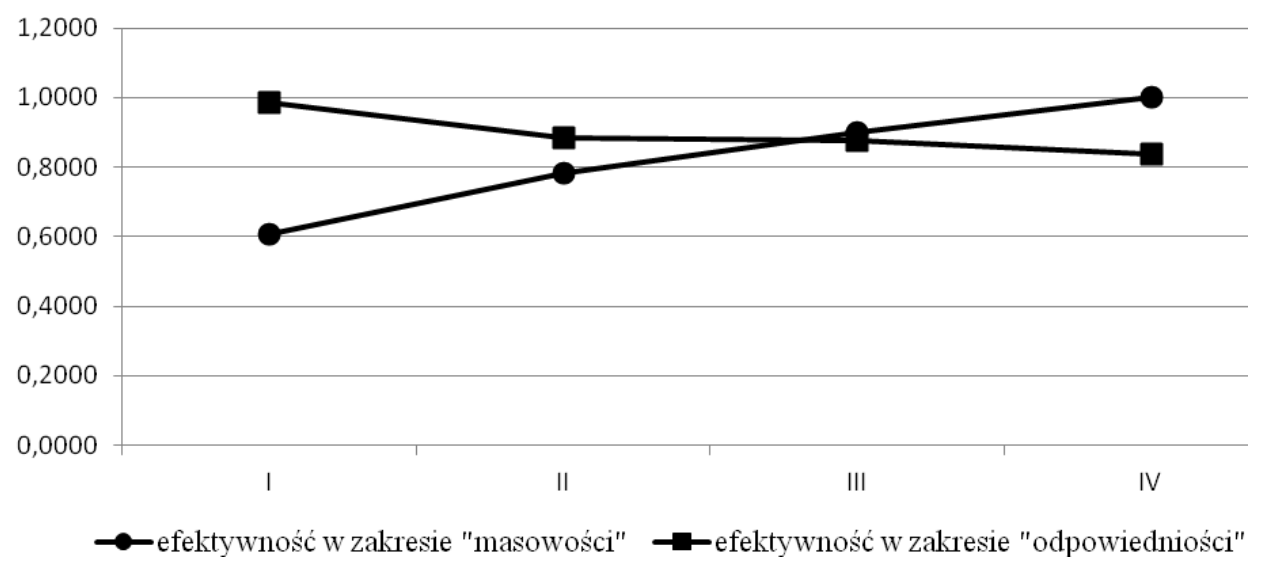

Źródło: opracowanie własne.

wartością współczynnika efektywności w zakresie „masowości” kształcenia i jednocześnie osiągają najwyższą średnią wartość współczynników efektywności w zakresie „odpowiedniości” kształcenia. Oznacza to, że województwa stawiające na „masowość” kształcenia zaniedbują aspekty zaspokajania wymagań rynku pracy, to znaczy ,produkuje się” mnóstwo osób z wyższym wykształceniem, których kierunek wykształcenia nie odpowiada zapotrzebowaniu na rynku pracy. Osoby takie z reguły po prostu nie znajduja zatrudnienia - nie zasilają szeregów kadr pracowniczych. Z drugiej strony wynikać to może z niskiej jakości kwalifikacji, gdyż -jak twierdzi G. S. Becke ${ }^{10}$ absolwenci tych szkół wyższych, w których dostęp do nauczycieli akademickich był słaby (województwa o wysokiej efektywności w zakresie „masowości” kształcenia), gorzej radza sobie na stanowiskach pracy, są mniej produktywni, co powoduje, że przedsiębiorcy niechętnie ich zatrudniają.

* $2007 \mathrm{r}$.

I grupa - podlaskie, kujawsko-pomorskie, pomorskie,

II grupa - wielkopolskie, zachodniopomorskie,

III grupa - małopolskie, śląskie, dolnośląskie, lubelskie, łódzkie, podkarpackie, lubuskie, warmińsko-mazurskie, mazowieckie, opolskie, świętokrzyskie.

Współzależności opisane wcześniej dla 2006 r. nadal można zaobserwować w 2007 r. (tabela 4 i wykres 3). Wraz ze wzrostem średniej wartości współczynnika efektywności w zakresie „masowości” kształcenia w obrębie wyróżnionych klas spada średni poziom wartości współczynnika efektywności w zakresie ,odpowiedniości” kształcenia w tych klasach. Należy mieć na

${ }^{10}$ G. S. Becker, op. cit. 


\section{Tabela 4}

Wartości średnich, odchyleń standardowych i współczynników zmienności efektywności w zakresie „masowości” kształcenia w 2007 r.

\begin{tabular}{|c|c|c|c|c|c|c|}
\hline \multirow[b]{2}{*}{$\begin{array}{c}\text { Numer } \\
\text { skupienia }\end{array}$} & \multicolumn{2}{|c|}{ Średnie } & \multicolumn{2}{|c|}{$\begin{array}{c}\text { Odchylenia } \\
\text { standardowe }\end{array}$} & \multicolumn{2}{|c|}{$\begin{array}{l}\text { Współczynniki } \\
\text { zmienności }\end{array}$} \\
\hline & $\begin{array}{l}\text { efektywność } \\
\text { w zakresie } \\
\text { „masowości” }\end{array}$ & $\begin{array}{l}\text { efektywność } \\
\text { w zakresie } \\
\text { „odpowied- } \\
\text { niości” }\end{array}$ & $\begin{array}{c}\text { efektywność } \\
\text { w zakresie } \\
\text { „masowości” }\end{array}$ & $\begin{array}{c}\text { efektywność } \\
\text { w zakresie } \\
\text { „odpowied- } \\
\text { niości” }\end{array}$ & $\begin{array}{l}\text { efektywność } \\
\text { w zakresie } \\
\text { „masowości” }\end{array}$ & $\begin{array}{c}\text { efektywność } \\
\text { w zakresie } \\
\text { „odpowied- } \\
\text { niości” }\end{array}$ \\
\hline I & 0,6569 & 0,9619 & 0,0313 & 0,0333 & $4,76 \%$ & $3,46 \%$ \\
\hline II & 0,7487 & 0,9356 & 0,0081 & 0,0910 & $1,08 \%$ & $9,73 \%$ \\
\hline III & 0,9520 & 0,8505 & 0,0496 & 0,0876 & $5,21 \%$ & $10,30 \%$ \\
\hline
\end{tabular}

Źródło: obliczenia własne.

\section{Wykres 3}

Srednie poziomy współczynników efektywności w skupieniach wyznaczonych na podstawie współczynników efektywności w zakresie „masowości” kształcenia w 2007 r.

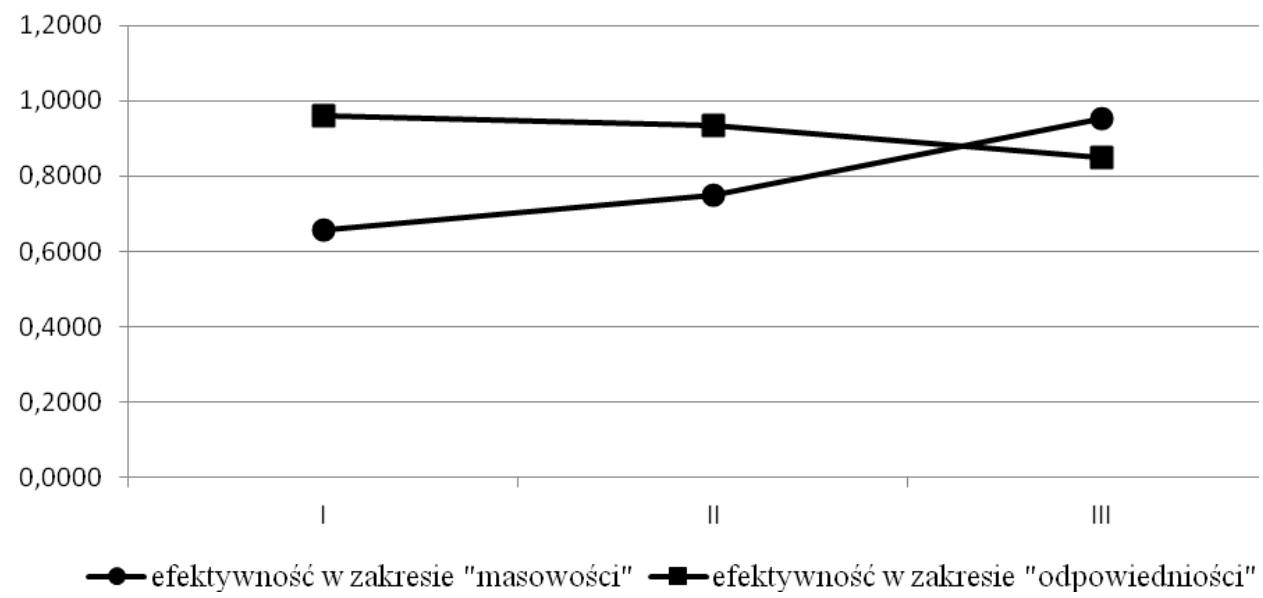

Źródło: opracowanie własne.

względzie przede wszystkim to, że współczynniki zmienności współczynników efektywności w zakresie ,odpowiedniości” kształcenia są zdecydowanie wyższe niż w wypadku współczynników efektywności w zakresie „masowości” kształcenia. Oznacza to, że wartości współczynników efektywności w zakresie „odpowiedniości” kształcenia w obrębie wyróżnionych skupień sa bardziej zróżnicowane, ponieważ miernik ten nie był kryterium klasyfikacji. Stąd zrodziła się konieczność sprawdzenia uzyskanych wyników i powtórzenia powyższych analiz, tym razem wykorzystując współczynnik efektywności w zakresie „odpowiedniości” kształcenia jako kryterium podziału. 
Dla dokonanych podziałów obliczono wartości średnie, odchylenia standardowe, zmienności współczynników efektywności dla każdego skupienia i uzyskano następujące wyniki:

* $2006 \mathrm{r}$.

I grupa - lubelskie, świętokrzyskie,

II grupa - łódzkie, małopolskie, mazowieckie, lubuskie, podkarpackie, dolnośląskie,

III grupa - wielkopolskie, warmińsko-mazurskie, śląskie, kujawsko-pomorskie,

IV grupa - podlaskie, pomorskie, zachodniopomorskie, opolskie.

\section{Tabela 5}

Wartości średnich, odchyleń standardowych i współczynników zmienności efektywności w zakresie ,odpowiedniości” kształcenia w 2006 r.

\begin{tabular}{|c|c|c|c|c|c|c|}
\hline \multirow[b]{2}{*}{$\begin{array}{c}\text { Numer } \\
\text { skupienia }\end{array}$} & \multicolumn{2}{|c|}{ Średnie } & \multicolumn{2}{|c|}{$\begin{array}{l}\text { Odchylenia } \\
\text { standardowe }\end{array}$} & \multicolumn{2}{|c|}{$\begin{array}{l}\text { Współczynniki } \\
\text { zmienności }\end{array}$} \\
\hline & $\begin{array}{l}\text { efektywność } \\
\text { w zakresie } \\
\text { „masowości” }\end{array}$ & $\begin{array}{c}\text { efektywność } \\
\text { w zakresie } \\
\text { „odpowied- } \\
\text { niości” }\end{array}$ & $\begin{array}{l}\text { efektywność } \\
\text { w zakresie } \\
\text { „masowości” }\end{array}$ & $\begin{array}{l}\text { efektywność } \\
\text { w zakresie } \\
\text { „odpowied- } \\
\text { niości” }\end{array}$ & $\begin{array}{l}\text { efektywność } \\
\text { w zakresie } \\
\text { „masowości” }\end{array}$ & $\begin{array}{l}\text { efektywność } \\
\text { w zakresie } \\
\text { „odpowied- } \\
\text { niości” }\end{array}$ \\
\hline I & 0,9168 & 0,7459 & 0,1177 & 0,0058 & $12,84 \%$ & $0,78 \%$ \\
\hline II & 0,8968 & 0,8426 & 0,0693 & 0,0300 & $7,73 \%$ & $3,56 \%$ \\
\hline III & 0,8120 & 0,9290 & 0,1668 & 0,0333 & $20,54 \%$ & $3,58 \%$ \\
\hline IV & 0,7255 & 0,9952 & 0,1712 & 0,0096 & $23,60 \%$ & $0,96 \%$ \\
\hline
\end{tabular}

Źródło: obliczenia własne.

\section{Wykres 4}

Średnie poziomy współczynników efektywności w skupieniach wyznaczonych na podstawie współczynników efektywności w zakresie „odpowiedniości” kształcenia w 2006 r.

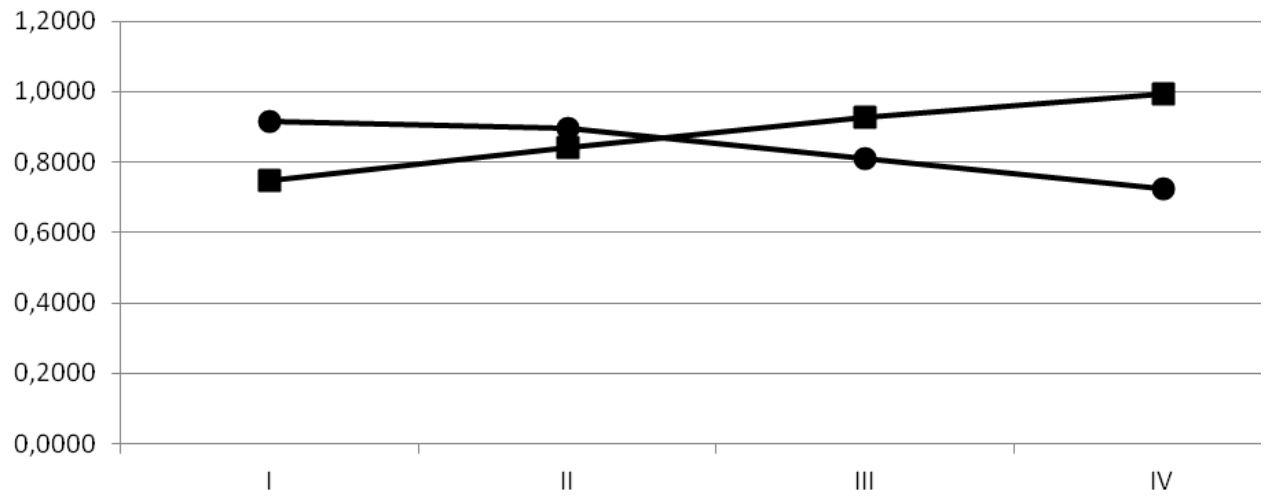

—efektywność w zakresie "masowości" ㄴefektywność w zakresie "odpowiedniości"

Źródło: opracowanie własne. 
* $2007 \mathrm{r}$.

I grupa - lubelskie, świętokrzyskie, łódzkie,

II grupa - mazowieckie, lubuskie, małopolskie, podkarpackie, wielkopolskie, warmińsko-mazurskie,

III grupa - podlaskie, śląskie, dolnośląskie, kujawsko-pomorskie,

IV grupa - pomorskie, zachodniopomorskie, opolskie.

\section{Tabela 6}

Wartości średnich, odchyleń standardowych i współczynników zmienności efektywności w zakresie „odpowiedniości” kształcenia w 2007 r.

\begin{tabular}{|c|c|c|c|c|c|c|}
\hline \multirow[b]{2}{*}{$\begin{array}{c}\text { Numer } \\
\text { skupienia }\end{array}$} & \multicolumn{2}{|c|}{ Średnie } & \multicolumn{2}{|c|}{$\begin{array}{l}\text { Odchylenia } \\
\text { standardowe }\end{array}$} & \multicolumn{2}{|c|}{$\begin{array}{l}\text { Współczynniki } \\
\text { zmienności }\end{array}$} \\
\hline & $\begin{array}{l}\text { efektywność } \\
\text { w zakresie } \\
\text { „masowości” }\end{array}$ & $\begin{array}{c}\text { efektywność } \\
\text { w zakresie } \\
\text { „odpowied- } \\
\text { niości” }\end{array}$ & $\begin{array}{l}\text { efektywność } \\
\text { w zakresie } \\
\text { „masowości” }\end{array}$ & $\begin{array}{l}\text { efektywność } \\
\text { w zakresie } \\
\text { „odpowied- } \\
\text { niości” }\end{array}$ & $\begin{array}{l}\text { efektywność } \\
\text { w zakresie } \\
\text { „masowości” }\end{array}$ & $\begin{array}{l}\text { efektywność } \\
\text { w zakresie } \\
\text { „odpowied- } \\
\text { niości” }\end{array}$ \\
\hline I & 0,9636 & 0,7474 & 0,0318 & 0,0015 & $3,30 \%$ & $0,20 \%$ \\
\hline II & 0,9259 & 0,8480 & 0,1003 & 0,0266 & $10,84 \%$ & $3,13 \%$ \\
\hline III & 0,7619 & 0,9484 & 0,1415 & 0,0211 & $18,57 \%$ & $2,23 \%$ \\
\hline IV & 0,8153 & 0,9963 & 0,1630 & 0,0064 & $19,99 \%$ & $0,65 \%$ \\
\hline
\end{tabular}

Źródło: obliczenia własne.

\section{Wykres 5}

Średnie poziomy współczynników efektywności w skupieniach wyznaczonych na podstawie współczynników efektywności w zakresie „odpowiedniości” kształcenia w 2007 r.

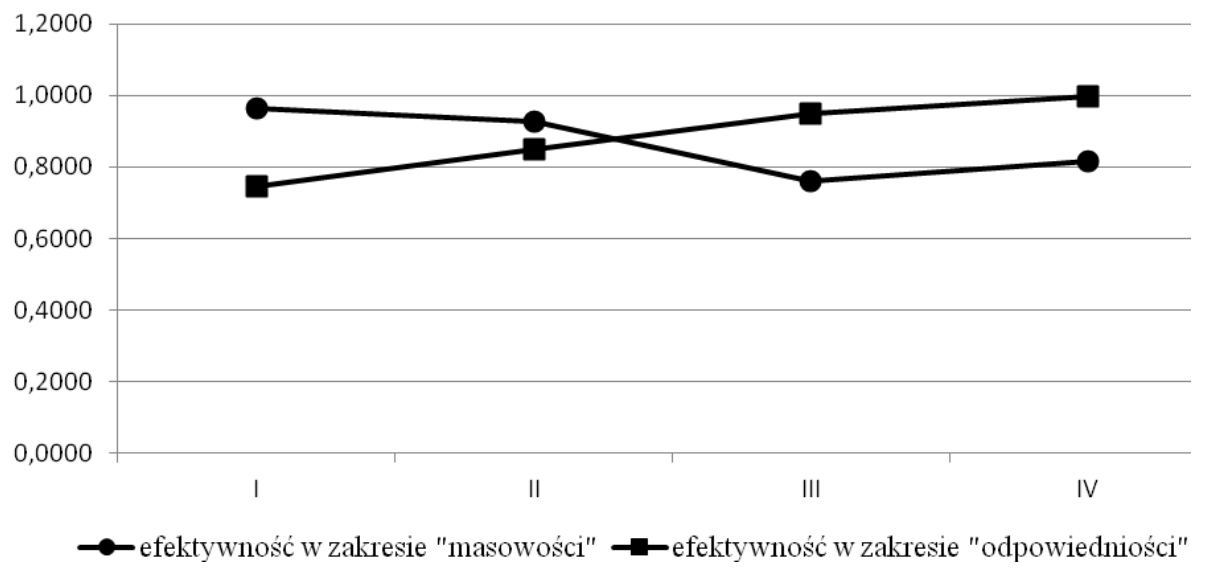

Źródło: opracowanie własne. 
Zmiana kryterium podziału potwierdziła zasadność wyciągniętych wcześniej wniosków. Wraz ze spadkiem średniej wartości współczynnika efektywności w zakresie „masowości” kształcenia w obrębie wyróżnionych klas wzrasta średni poziom wartości współczynnika efektywności w zakresie „odpowiedniości” kształcenia w tych klasach w obu analizowanych okresach.

\section{EDUKACJA WYŻSZA W WOJEWÓDZTWIE WIELKOPOLSKIM}

\section{1. „Masowość” kształcenia w województwie wielkopolskim}

Województwo wielkopolskie odznaczało się wskaźnikiem efektywności technicznej w zakresie „masowości” kształcenia w kolejnych latach 2006 i 2007 równym, odpowiednio, 0,763 oraz 0,743 . Oznacza to, że gdyby województwo zredukowało w 2006 r. (2007 r.) swoje nakłady do poziomu $76,3 \%(74,3 \%)$ faktycznie poniesionych w $2006 \mathrm{r}$. (2007 r.), czyli do poziomu $39,9(39,1)$ nauczycieli akademickich na 1000 studentów oraz $0,95(0,96)$ szkół wyższych na mieszkańca, byłoby w pełni efektywne. Innymi słowy, taki sam poziom wykształcenia mierzony odsetkiem osób z wykształceniem wyższym województwo wielkopolskie mogłoby osiagnaćc, zatrudniając mniej nauczycieli akademickich na studenta oraz zamykając część szkół wyższych.

Wzorcami dla województwa wielkopolskiego pod względem efektywności wykorzystania nakładów do podnoszenia kwalifikacji (,masowość” kształcenia) w 2006 r. były województwa świętokrzyskie i warmińsko-mazurskie, natomiast w 2007 r. województwa świętokrzyskie i opolskie. Jeśli chodzi o dostęp do nauczycieli akademickich w 2006 r. (2007 r.) w 66\% (56\%) swoja technologię województwo powinno wzorować na technologiach stosowanych przez województwo warmińsko-mazurskie (opolskie), natomiast „,tylko” w 34\% (44\%) na technologiach stosowanych przez województwo świętokrzyskie (świętokrzyskie). Województwa świętokrzyskie oraz warmińsko-mazurskie potrafiłyby wspólnie w 2006 r. uzyskać co najmniej 13,4\% osób z wykształceniem wyższym mniejszym nakładem równym: 39,96 nauczycieli akademickich na 1000 studentów (co stanowi 76\% technologii empirycznej województwa wielkopolskiego) oraz 0,95 szkół wyższych przypadających na jednego mieszkańca (co stanowi 76\% technologii empirycznej województwa wielkopolskiego). Z kolei w 2007 r. województwa opolskie oraz świętokrzyskie byłyby w stanie wspólnie uzyskać odsetek osób z wykształceniem wyższym na poziomie co najmniej 13,02\% mniejszym nakładem równym: 39,11 nauczycieli akademickich na 1000 studentów (co stanowi 74,3\% technologii empirycznej województwa wielkopolskiego) oraz 0,97 szkół wyższych przypadających na jednego mieszkańca (co stanowi 74,3\% technologii empirycznej województwa wielkopolskiego; por. tabela 7). 


\section{Tabela 7}

Technologia optymalna dla województwa wielkopolskiego i jej podstawowe charakterystyki w latach 2006 i 2007

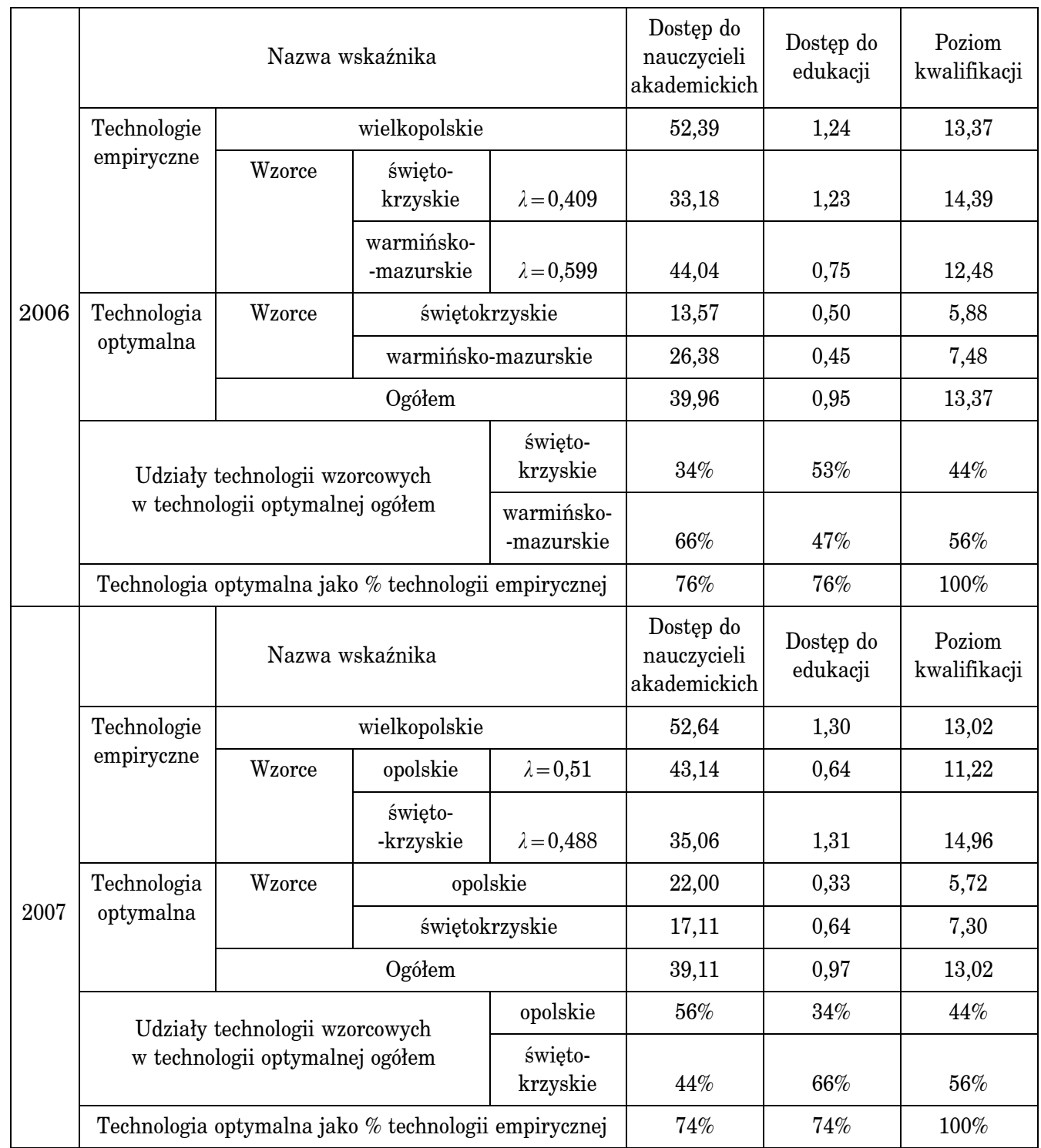

Źródło: obliczenia własne. 


\section{2. „Odpowiedniośc” kształcenia w województwie wielkopolskim}

Jeśli chodzi o efektywność w zakresie „odpowiedniości” kształcenia, województwo wielkopolskie odznaczało się wskaźnikiem efektywności technicznej w kolejnych latach równym, odpowiednio, 0,899 oraz 0,871 . Oznacza to, że gdyby województwo zredukowało w 2006 r. (2007 r.) odsetek osób $\mathrm{z}$ wykształceniem wyższym do poziomu $89,9 \%(87,1 \%)$ faktycznie istniejącego w 2006 r. (2007 r.), czyli do poziomu 12,01\% (11,36\%), byłoby w pełni efektywne. Ogólnie rzecz ujmując, taki sam odsetek zatrudnionych $\mathrm{z}$ wykształceniem wyższym oraz taki sam odsetek pracujących po raz pierwszy absolwentów szkół wyższych województwo wielkopolskie mogłoby osiagnąc przy zdecydowanie mniejszym odsetku osób z wykształceniem wyższym.

Województwo wielkopolskie swoją nieefektywność pod względem „,odpowiedniości" kształcenia w 2006 r. powinno wzorować na województwach opolskim i pomorskim, natomiast w $2007 \mathrm{r}$. - na województwach opolskim i zachodniopomorskim. Jeśli chodzi o poziom wykształcenia w 2006 r., w $67 \%$ województwo wielkopolskie powinno wzorować się na technologiach stosowanych przez województwo opolskie, w $33 \%$ na technologiach stosowanych przez województwo pomorskie, natomiast w kolejnym roku w 95\% swoje technologie w zakresie poziomu wykształcenia województwo wielkopolskie powinno wzorować na technologiach stosowanych przez województwo opolskie, a ,tylko” $\mathrm{w} 5 \%$ na technologiach stosowanych w województwie zachodniopomorskim. Województwa opolskie oraz pomorskie potrafiłyby wspólnie w 2006 r. uzyskać co najmniej $20,3 \%$ osób zatrudnionych $\mathrm{z}$ wykształceniem wyższym wśród wszystkich pracujących oraz $20,89 \%$ pracujących po raz pierwszy absolwentów szkół wyższych mniejszym nakładem odsetka osób z wykształceniem wyższym równym $12 \%$ (co stanowi $90 \%$ technologii empirycznej województwa wielkopolskiego). Z kolei w 2007 r. województwa opolskie oraz zachodniopomorskie mogłyby wspólnie uzyskać co najmniej 19,21\% osób zatrudnionych z wykształceniem wyższym wśród wszystkich pracujących oraz $21,61 \%$ pracujących po raz pierwszy absolwentów szkół wyższych mniejszym nakładem odsetka osób z wykształceniem wyższym równym $11,35 \%$ (co stanowi $87 \%$ technologii empirycznej województwa wielkopolskiego; por. tabela 8).

\section{PODSUMOWANIE}

W pełni efektywnymi województwami pod względem „masowości” kształcenia w latach 2006-2007 były województwa: mazowieckie oraz świętokrzyskie. Województwo mazowieckie zdecydowanie słabiej wypadło pod względem efektywności w zakresie „odpowiedniości” kształcenia w obu latach, osiągając współczynniki efektywności na poziomie, odpowiednio: 0,844 i 0,815 (co dało w 2006 r. miejsce 9 w rankingu województw nieefektywnych, a w 2007 r. miejsce 11). Województwo świętokrzyskie z kolei osiągnęło takie same wartości współczynników efektywności w zakresie „,odpowiedniości kształcenia w anali- 


\section{Tabela 8}

Technologia optymalna dla województwa wielkopolskiego i jej podstawowe charakterystyki w latach 2006 i 2007

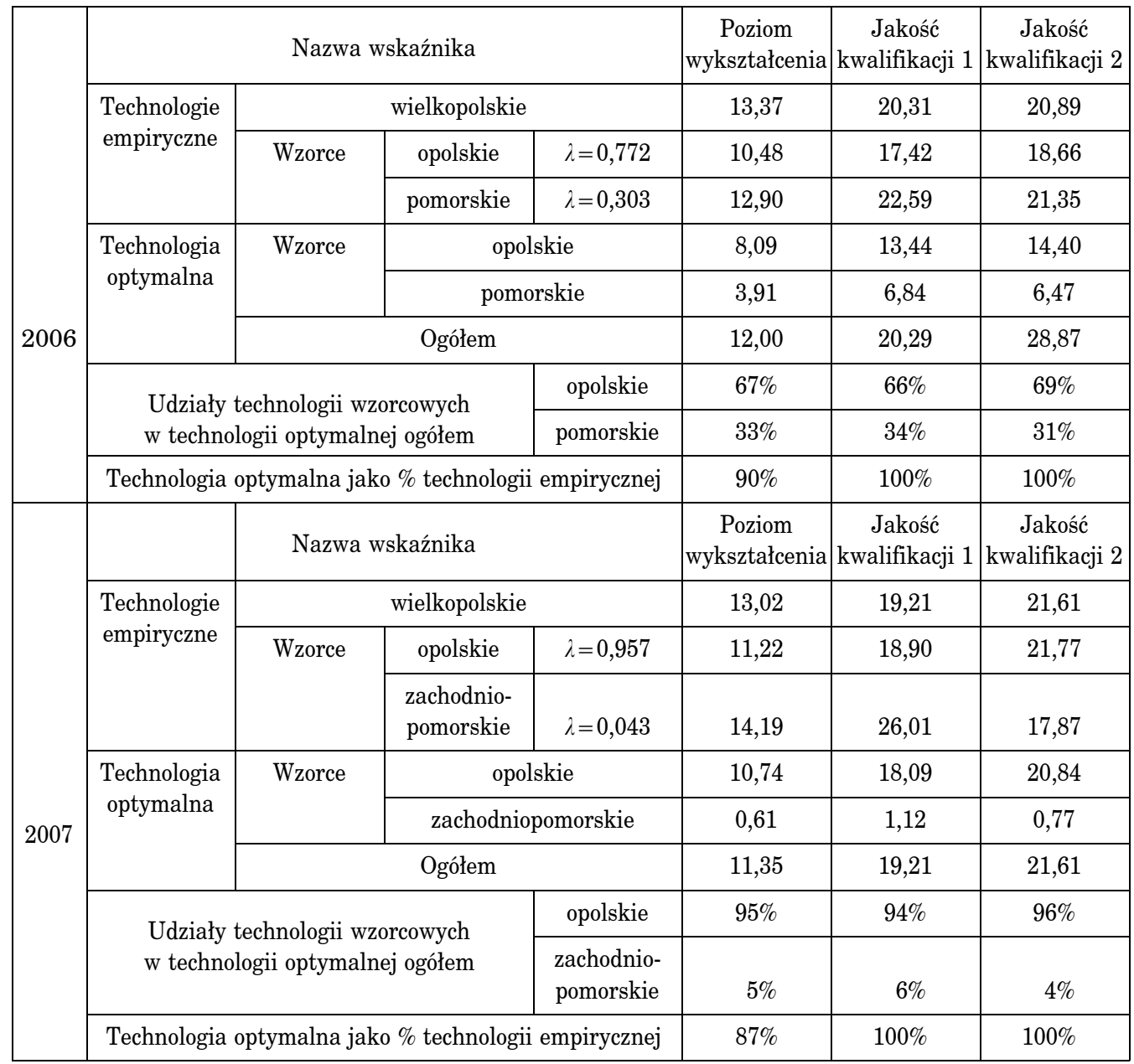

Źródło: obliczenia własne.

zowanych okresach na poziomie 0,75 (co dało w 2006 r. miejsce $12 \mathrm{w}$ rankingu województw nieefektywnych, a w 2007 r. miejsce 13).

W pełni efektywnymi województwami tym razem pod względem „odpowiedniości” kształcenia w obu analizowanych okresach były województwa: opolskie oraz zachodniopomorskie. Województwo zachodniopomorskie słabo wypadło pod względem ,,masowości” kształcenia, osiagając w latach 2006 i 2007 współczynniki efektywności na poziomie, odpowiednio, 0,718 i 0,754 (co dało w 2006 r. miejsce 10 w rankingu województw nieefektywnych, a w 2007 r. miejsce 9). Województwo opolskie z kolei było w 2007 r. województwem w pełni 
efektywnym nie tylko w zakresie „odpowiedniości”, lecz także w zakresie „masowości” kształcenia. Co więcej, w 2006 r. pomimo pełnej efektywności w zakresie ,odpowiedniości” uplasowało się na 1 miejscu w rankingu uwzględniającym wartości współczynników efektywności w zakresie „masowości” kształcenia, osiągając wartość tego współczynnika równą 0,965. Pomimo to zauważalna jest istotna ujemna korelacja pomiędzy współczynnikami efektywności w zakresie „masowości” a „odpowiedniości” kształcenia.

Przeprowadzone analizy potwierdzają zatem przypuszczenia różnych badaczy zajmujących się pomiarem kapitału ludzkiego. Uważają oni bowiem, że zdecydowanie lepiej dla jakości wykształcenia, jeżeli na studenta przypadać będzie jak największa liczba nauczycieli. Rzeczywiście województwa, które charakteryzowały się niską wartością współczynnika efektywności w zakresie „masowości” kształcenia (zbyt wysokimi nakładami), uzyskiwały taki sam poziom rezultatu (odsetek osób z wykształceniem wyższym) i były zdecydowanie bardziej efektywne pod względem „odpowiedniości” kształcenia. Taką sytuację można wyjaśnić na dwa sposoby, przyjmując pewne założenia:

1. Jeżeli mamy do czynienia $\mathrm{z}$ województwami o podobnym poziomie wykształcenia (odsetek osób $\mathrm{z}$ wykształceniem wyższym), to niższe wartości współczynnika efektywności w zakresie „masowości” kształcenia wynikaja z większej liczby zatrudnionych nauczycieli akademickich oraz większej dostępności do edukacji, natomiast wyższe na odwrót. Wtedy różnice w wartościach współczynnika efektywności w zakresie ,odpowiedniości” kształcenia (pokrywające się z różnicami wartości współczynnika efektywności w zakresie „masowości” kształcenia) wynikaja właśnie z lepszej jakości wykształcenia, jakie uzyskują osoby opuszczające uczelnie. Osoby takie są pożądane na rynku pracy i rozchwytywane przez przedsiębiorców w tych województwach o niższych wskaźnikach efektywności w zakresie „,masowości” kształcenia.

2. Jeżeli mamy do czynienia $\mathrm{z}$ województwami o zdecydowanie różnym poziomie wykształcenia (odsetek osób z wykształceniem wyższym) oraz podobnych nakładach w postaci dostępu do kadry akademickiej i dostępu do edukacji, to wyższe wartości współczynnika efektywności w zakresie „masowości” kształcenia wynikają przede wszystkim z mniejszej liczby studentów oraz mniejszej dostępności do edukacji. Województwa te „rozdaja” masowo dyplomy ukończenia szkół wyższych, zaniedbując aspekty jakościowe oraz zgodność kierunków kształcenia z wymogami stawianymi na rynku pracy. Wtedy różnice w wartościach współczynnika efektywności w zakresie „odpowiedniości” kształcenia (pokrywające się z różnicami wartości współczynnika efektywności w zakresie „masowości” kształcenia) wynikają właśnie z przesycenia rynku pracy ofertami osób z wykształceniem wyższym. Rynek pracy potrzebuje konkretnych osób z określonymi kwalifikacjami - najlepiej osób z wykształceniem wyższym, ale po ściśle określonych kierunkach. Osoby posiadające wykształcenie niezgodne $\mathrm{z}$ wymogami rynku pracy mimo wyższego wykształcenia nie są na nim pożądane i nie znajdują zatrudnienia, dlatego masowa produkcja dyplomów nie przekłada się proporcjonalnie na zatrudnienie w tych województwach o wyższych wskaźnikach efektywności w zakresie „masowości” kształcenia. 
Wnioski w niniejszym artykule zostały sformułowane na podstawie pewnych założeń, a mianowicie, że w każdym $\mathrm{z}$ analizowanych regionów zapotrzebowanie rynku pracy na osoby $\mathrm{z}$ wykształceniem wyższym jest takie samo. W myśl tego założenia różnice $\mathrm{w}$ zatrudnieniu wynikać moga rzeczywiście głównie $\mathrm{z}$ różnic w efektywnościach analizowanych procesów.

Dwa sformułowane wnioski otwierają drogę do przeprowadzenia kolejnych badań. Po pierwsze, warto byłoby przeprowadzić to badanie przy uwzględnieniu wskaźników oceniających poziom wykształcenia absolwentów różnych kierunków naukowych (zwraca się często uwagę na przyszłościowość kierunków statystycznych, matematyczno-przyrodniczych, informatycznych, ponieważ na wiedzę uzyskaną właśnie na tych kierunkach będzie największe zapotrzebowanie w gospodarce w XXI w.), czy ustaleniu faktycznego (być może zróżnicowanego między województwami) zapotrzebowania rynku pracy na osoby z wykształceniem wyższym (poziom rozwoju sektora usługowego, poziom rozwoju sektora badawczo-rozwojowego, stopień innowacyjności przedsiębiorstw itd.). Po drugie, interesujące i zarazem pozwalające na potwierdzenie dwóch sformułowanych w podsumowaniu wniosków byłoby pogrupowanie województw ze względu na poziom wykształcenia, następnie ze względu na dostęp do kadry akademickiej i dostęp do edukacji oraz dla każdego przypadku przeprowadzenie analizy DEA w obrębie wyróżnionych klas. Wtedy $\mathrm{w}$ ramach jednej analizy znalazłyby się jedynie województwa o podobnym poziomie wykształcenia, a w drugim przypadku - o podobnym dostępie do kadry akademickiej i edukacji.

mgr Monika Osinska

Uniwersytet Ekonomiczny w Poznaniu

\title{
APPLICATION OF THE CCR-DEA MODEL TO THE ASSESSMENT OF THE EFFECTIVENESS OF HIGHER EDUCATION IN POLAND
}

\author{
Summary
}

The capabilities of the personnel that potential employers value change together with the external environment in which companies operate. Likewise, the demands of the labour market require a change in the role of higher education whose main objective today is seen to be preparation of highly specialised professionals. However, although higher education establishments ensure equal access to education in all possible fields, they often educate specialists for jobs that are not needed, while the degree of specialisation of those who are needed is only too frequently far from employers' expectations. Consequently, graduates with diplomas encounter serious difficulties in the job market, including potential unemployment. The main goal of this paper was to determine the effectiveness of higher education in Poland and its individual regions (voivodships) in the years 2006-2007 and compare the results regarding the relationships between mass education and the suitability of education for the job market. The analysis was carried out using the CCR-DEA model. 
